\title{
FELHASZNÁLÓAZONOSÍTÁS A KÖNYVTÁRI DIGITÁLIS SZOLGÁLTATÁSOKHOZ
}

\author{
TAKÁCS DÁNIEL
}

Budapesti Ügyvédi Kamara, szolgáltatási igazgató

\begin{abstract}
ABSZTRAKT
A könyvtári szolgáltatások egyik gyenge pontja a digitális környezetben történő felhasználóazonosítás. A megfelelő autentikációs rendszer kialakításához szükséges a jogszabályi környezet tisztázása is, mivel jelenleg csupán olyan törvények léteznek, amelyek vagy a digitális adatkezeléssel, vagy a könyvtárakkal függnek össze, a kettő között nincs, vagy csak nagyon áttételes az összefüggés. Az autentikációs környezet kialakítására ma több lehetőség is adódik, a kereskedelmi szolgáltatóktól kezdve a hitelesített tanúsítványszolgáltatókon át a kormányzati szereplőkig, ezek közül kell kiválasztani az „átlag” állampolgárok számára a legkönnyebben elérhető, legegyszerủbben használható megoldást. Az ügyfélkapus azonosítás bevezetése mellett számtalan technikai, jogi és társadalmi érv szól, ráadásul mind a fejlesztés, mind pedig az üzemeltetés szempontjából az egyik legolcsóbb lehetőség. Természetesen nem csak előnyei, hátrányai is vannak ennek az azonosítási eljárásnak, de ezek jobbára olyan szempontok, amelyek a többi megoldásnál is szerepet játszanak valamilyen mértékben. Ráadásul nem lehet eltekinteni a könyvtárak intézményi és informatikai lehetőségeitől sem, amelyek szintén jelentősen befolyásolják ezeket a paramétereket. Az egységes azonosítási rendszer szélesre tárja a létrehozható szolgáltatások körét és az ezt kiszolgáló intézményi és informatikai háttér rugalmasságát is rendkívül nagymértékben megnövelheti. Így olyan könyvtári hálózat jöhet létre, amely ugyanazt a felhasználói élményt tudja nyújtani szinte bárhol, illetve olyan személyre szabott szolgáltatások jöhetnek létre, amelyek megoldhatják a jelenlegi, a könyvtári szolgáltatások távoli elérésével kapcsolatos jogi és technológiai kérdéseket is.
\end{abstract}

\section{Szabályozási környezet}

Minden digitális szolgáltatás egyik kritikus pontja az adott online vagy offline terméket használó személy azonosítása. Ez történhet akár a jogosultság ellenőrzése céljából (ez különösen fontos fizetős szolgáltatások esetében, de akár valamilyen jogszabályi megfelelőséget is ellenőrizhetünk vele), vagy akár a megfelelő háttérinformációk és kontextus hozzárendelése (például a szolgáltatás személyre szabása) során.

Jelenleg Magyarországon több jogszabály is foglalkozik a digitális felhasználó-azonosításhoz szükséges adatbázisok kialakításával és múködtetésével. A jogszabályok elsősorban a közhitelesség és az elsődlegesség szemszögéből, illetve a kereskedelmi szolgáltatásokkal kapcsolatos szempontokból írják le ezeket a felhasználók azonosítására szolgáló adatállományokat és múködésüket, amelyek a könyvtárak gyakorlatában nem minden esetben értelmezhetők és alkalmazhatók, azonban a bennük foglaltak hatással lehetnek az olvasói nyilvántartásokra is. 
TAKÁCS DÁNIEL

A szabályozási háttér legfontosabb jogszabályai a 2011. évi CXII. törvény az információs önrendelkezési jogról és az információszabadságról („,info törvény”) ${ }^{1}$, és a 2013. évi CCXX. törvény az állami és önkormányzati nyilvántartások együttmúködésének általános szabályairól (,interoperabilitási törvény”)². A törvények előírásait kiegészítik az egyes, a fenntartó által létrehozott helyi szabályozások az adott könyvtár által vezetett nyilvántartásokról.

$\mathrm{Az}$ info törvény írja le az elsődleges és származtatott adatbázisok rendjét, azaz hogy mely körben keletkeznek a nyilvántartási adatok, és azok milyen rendben adhatók át az azokat felhasználó egyéb intézményeknek. Az interoperabilitási törvény rendelkezik az adatbázisok közötti adatcserék rendjéről és módjáról.

Jelenleg az 1997. évi CXL. törvény a muzeális intézményekről, a nyilvános könyvtári ellátásról és a közművelődésről („könyvtári törvény”) nem rendelkezik a könyvtárak által vezetett felhasználói (és egyéb) adatbázisok tartalmáról és kezelési módjáról. Így olyan központi előírás, amely egységesen definiálja a könyvtári nyilvántartásokat, nem létezik, és ez súlyos hiányosság. Természetesen annak fenntartása mellett, hogy biztosítani kell az egyes intézmények szakmai szabadságát az általuk nyújtott szolgáltatások és kezelt gyűjtemények leírásának tartalmát és módját illetően (bár az erre vonatkozó könyvtári és egyéb szabványok hasonló szerepet tölthetnek be).

Az egységes azonositási rendszeren alapuló könyvtári hálózatok.

A könyvtárak felhasználókról vezetett nyilvántartásai származtatott adatbázisok, amelyek elsődleges célja az állomány és a szolgáltatások használóinak személyes azonosítása a természetes személyazonosító adatok ${ }^{4}$ alapján. Ennek célja lehet a könyvtár és szolgáltatásai használatára vonatkozó jogosultság megállapítása és ellenőrzése, a dokumentumkölcsönzés (ehhez kellenek a jogosultsági információk és a nyilvántartásból származó historikus adatok az esetleges elmaradás és tartozás megállapításához), valamint a kapcsolattartás (ezek jellemzően önkéntes alapon vagy a helyi szabályozás nyomán megadandó adatok). Olyan egyéb felhasználási területeket is meg lehet említeni, amelyek talán még nem elterjedtek, de a nyugati minták és a technológiai fejlődés alapján hamarosan számítani lehet széleskörú megjelenésükre: fizetési megoldások (micropayment) megjelenése (előfizetések, tagság, késedelem, fénymásolás stb. dijának kifizetése), személyre szabott ajánlók az állomány alapján (historikus keresési és kölcsönzési adatok), összekapcsolás könyvesboltok adatbázisaival stb.

Az így létrejövő nyilvántartások több szinten is kapcsolódhatnak egymással:

1. Ezek legnyilvánvalóbbika a lokális kapcsolat, amely adott intézményi vagy földrajzi határok között működő intézmények adatbázisai között jöhet létre, mint pl. egy település könyvtára és a településen múködő iskolai könyvtár(ak), vagy egy egyetem kari és intézeti könyvtári nyilvántartásának összekapcsolódása. Jelenleg több ilyen kapcsolati rendszer múködik, mint például a Fővárosi Szabó Ervin Könyvtár vagy a Debreceni Egyetem Egyetemi és Nemzeti Könyvtár olvasói nyilvántartása. 
2. Hálózati kapcsolat akkor jöhet létre, ha a résztvevô intézmények szakmai vagy szervezeti szempont szerint szerveződnek. Ilyen lehet egy terület szakkönyvtárainak, az egyetemek könyvtárainak vagy egy adott megye/régió könyvtárainak hálózata.

3. A legfelső szint az országos, amelynek keretében az országban nyilvános könyvtári szolgáltatást megvalósító valamennyi intézmény kapcsolódik egymással, így az egy helyen keletkező felhasználói adat - megfelelő jogosultságok birtokában - azonnal elérhető lesz bárhol.

\section{Hitelesitési lehetöségek.}

Az egyik legfontosabb és a legegyszerűbben megvalósítható cél a felhasználói (olvasói) azonosítás (autentikáció) elvégzése online, digitális környezetben. Ez abból áll, hogy egy fizikai entitást (az adott személyt) összekötünk egy lentebb részletezett forrás által megerősített (hitelesített) online entitással. Ahhoz, hogy ezt a funkciót valamilyen elektronikus autentikációs rendszerként is megvalósítsuk, több lehetőség is rendelkezésünkre áll:

1. Több integrált könyvtári rendszer (IKR) is lehetővé teszi a felhasználóknak, hogy a róluk nyilvántartott adatok alapján (ez első sorban e-mail cím) létrehozzanak egy digitális entitást, fiókot (accountot), amellyel leginkább a kölcsönzési adatokhoz férhetnek hozzá (beleértve az előjegyzést, a kölcsönzés meghosszabbítását stb.). Adott esetekben ez kiegészülhet a személyes adatok bizonyos szintű módosítási lehetőségével is (telefonszám, e-mail cím). Ennek az azonosításnak komoly hátránya, hogy a jogosultság személyes megjelenés nélkül nem hitelesíthető (és biztonsági szempontból is nagyon kezdetleges), így például a távoli beiratkozás ezen a módon nem tud megvalósulni.

2. Néhány helyen, főleg egyetemeken, van arra lehetőség, hogy a könyvtári felhasználói adatbázist összekössék valamilyen külső nyilvántartással - adott esetben a hallgatói és oktatói adatbázissal. Ennek köszönhetően a nyilvántartás adminisztrációja lecsökken, hiszen van egy könyvtáron kívüli szervezet, amely valamilyen azonosító alapján (pl. a tanulmányi rendszerben használt egyedi kód alapján) tanúsítja a jogosultságokat. Ez a megoldás erôsen függvénye az adott külső intézményi nyilvántartás lehetôségeinek, sokszor pedig a könyvtárnak nincsen akkora súlya vagy lobbiereje az intézménynél és az IKR szolgáltatójánál, hogy az ehhez szükséges fejlesztéseket megvalósíttassa.

Elvi síkon minden hitelesítést igénylő szolgáltató, így a könyvtárak részére is rendelkezésre állnak azok a külső hitelesítési szolgáltatások, amelyek (leegyszerűsítve) korlátozó feltétel nélkül teszik lehetôvé a regisztrációt. Ezek között vannak állami és gazdasági szereplők, mint például a Nemzeti Infokommunikációs Szolgáltató Zrt. (NISZ) által üzemeltetett, a belügyminisztériumi Közigazgatási és Elektronikus Közszolgáltatások Központi Hivatala (KEKKH) nyilvántartáson alapuló magyarorszag.hu-s kormányzati ügyfélkapu (és ezzel összekapcsolva az új személyigazolvány), az elektronikus tanúsítvány-kibocsátó szolgáltatók (Microsec Zrt., Netlock Kft.), vagy akár az olyan vállalatok, mint a Yahoo, a Microsoft, a Twitter, a Facebook és a Google. Az ezekhez történő 


\section{TAKÁCS DÁNIEL}

csatlakozásnak jellemzően inkább informatikai feltételei vannak, így lehetőséget biztosítanak mindenki számára. Közös jellemzőjük a magasabb fokú biztonság (pl. kétlépcsős autentikációs lehetőség).

3. Végül pedig, bár a közeljövőben elterjedésükre nem kell számítani, rendelkezésre állnak azok a biometrikus azonosítási lehetőségek, amelyek az egyre több helyen megjelenő ujjlenyomat-olvasókat használhatják (sőt, ide lehet sorolni az új személyi igazolványt is), de müködhetnek akár arcfelismerés alapján vagy retinaszkennerrel is). Adott esetben komoly érvek merülhetnek fel a kereskedelmi szolgáltatók mellett is (Google, Facebook), de jelen tanulmány kereteibe ezek összehasonlítása nem fér bele, csupán az állami nyilvántartáson nyugvó ügyfélkapus megoldás lehetőségeit kívánom tárgyalni. Azt azonban mindenképpen el kell mondani, hogy a legnagyobb online hitelesítés-szolgáltatók (így a példának felhozott Facebook és a Google is) az általuk kezelt felhasználói profilokat, entitásokat elsősorban kereskedelmi célokra használják fel, így minden olyan szolgáltatás, amelyet kizárólag ilyen kapukon keresztül tesznek elérhetővé, végső soron rákényszeríti a felhasználókat, hogy maguk is termékké váljanak a hirdetési piacon. (Ennek részben folyományaként az is megállapítható, hogy az állami vállalatok és intézmények gyakorlatilag diszkriminálhatják a szolgálni kívánt állampolgárokat ezen eszközök használatával, amennyiben akár kommunikációs csatornaként, akár azonosítási eszközként alkalmazzák kizárólagos jelleggel.) Fő szabályként, elvárásként az fogalmazható meg, hogy másodlagos lehetőségként nem hogy megengedett, hanem erősen ajánlott lehetne az elfogadásuk, ugyanakkor csak és kizárólag egy olyan hitelesítési rendszerhez rendelve, amely független az online kereskedelmi szereplőktől (a függetlenek közé értem a tanúsítványokat kibocsátó vállalatokat is).

\section{Ügyfélkapus azonositás}

Az intézmények számára az egyik legegyszerübb és legbiztonságosabb, a felhasználók számára pedig a legolcsóbb lehetôség a kormányzati Ügyfélkapu használata, amely jelenleg már elérte a kritikus tömeget, megfelelő módon elterjedt. Mára számtalan szervezet, szolgáltatás teszi lehetővé az ügyfélkapus hitelesítést, és az elérhető állami szolgáltatások száma is meglehetősen nagy (erről sajnos pontos kimutatás tudomásom szerint nincsen). A regisztráltak száma folyamatosan és meredeken nő (a 2006-os 2-300 000 felhasználószám mára eléri a 2 millió főt), és a belépések száma is meghaladja a havi 16 millió alkalmat a 2009-es havi 6 millióhoz képest. ${ }^{5}$

Az ügyfélkapun alapuló azonosítási megoldás azért is biztonságosabb a könyvtárak szempontjából, mert országos szinten mindenkiről tartalmaz adatot, ráadásul ez szinkronban van a személyi igazolványon szereplő információkkal (természetesen ezeket az elvi alapvetéseket gyakran írják felül ügyintézői vagy állampolgári gondatlanságok). A természetes személyazonosító adatok vonatkozásában pedig ez a nyilvántartás az elsődleges és közhiteles adatforrás. A szolgáltatás összekapcsolódik egyéb, a NISZ által fejlesztett vagy koordinált szolgáltatással (pl. az Általános Nyomtatványkitöltő program, az ÁNYK használata adózási, bírósági és cégügyekben, intézmények egymás közti kommunikációja 
a hivatali kapun keresztül). A rendszer ingyenes mind az intézmények, mind pedig a magánszemélyek számára (sőt, utóbbiak esetében a magyar állampolgárság nem követelmény, ügyfélkaput nyithat bárki, térítés fejében pedig egy személy több regisztrációt is végezhet). Az intézmények számára fontos lehetőséget jelent a hivatali kapu, amely a szervezetek közötti információ- és dokumentumcserét hitelesíti, de lehetôvé teszi az ügyféllel történő hiteles kapcsolattartást is (így jogilag megegyezik a tértivevényes levelezéssel), és az ügyfél számára is megnyilik az ÁNYK-n keresztüli hitelesített dokumentumbeadás lehetősége.

Amennyiben egy ilyen, országos szintű ügyfélkapus azonosítási rendszer létrejön, akkor a könyvtárak három dolgot nyernek egyszerre:

1. Olyan létező törzsadatbázisra építhetnek, amelynek gondozása és az ezzel járó felelősség nem a jelenlegi intézményi rendszert terheli, hanem külső (kormányzati) szereplőn nyugszik. Ennek közhitelessége folytán feltételezhető, hogy Magyarországon ennél kurrensebb személyi nyilvántartás nem létezik.

2. Mivel a jelenleg is fejlesztett nyilvántartás egyik fô célja és erénye a különböző digitális identitások összekapcsolása, elméletileg lehetséges a központi nyilvántartás kiegészítése a könyvtári tagságok információival. Ennek következményeképpen létrejöhet egy olyan egységes nyilvántartási rendszer, amely kompatibilissé és egymás számára átjárhatóvá teszi az egyes lokális nyilvántartásokat.

3. Amennyiben ez a rendszer ebben a formában létrejön, a jelenleg bevezetés alatt álló, chippel ellátott személyi igazolvány alkalmas lesz az online mellett az offline autentikációra és a könyvtári funkciók használatára, így a két azonosítási rendszer nem kíván két külön igazolványt vagy dokumentumot.

A központi felhasználó-kezelés technikailag és folyamatilag is több feltételt támaszt. Technikailag a legfontosabb az egységes adatkezelési szabvány, amely igazodik a kormányzati adatbázishoz is. Ez egyrészt megvalósulhat minden egyes IKR-ben (ennek költsége a legmagasabb a lehetőségek közül), de független alkalmazásként is, amely a megfelelő Application Programming Interface-szel (API-val ${ }^{6}$ ) csatlakozik a különböző könyvtári rendszerekhez.

Jogi szempontból kérdéses lehet, hogy mennyire biztosítható az átjárhatóság és a láthatóság az adatbázisok között, de a magyarorszag.hu adatbázissal mindenképpen megoldható a folyamatos és állandó adatkapcsolat (pl. egy költözés esetén azonnal módosulhat a címadat). A könyvtári, lokális nyilvántartások közötti állandó és folyamatos adatkapcsolat mellett mind a felhasználók, mind pedig az intézmények érdekében szólnak érvek. Előbbiek számára fontos lehet a korábbi, kölcsönzésekkel, keresésekkel kapcsolatos információk mozgásával megvalósuló komfortérzet (számíthat ugyanarra az információs és szolgáltatási környezetre, amit az előző helyen kialakított), utóbbiak számára pedig az adott személlyel kapcsolatos rizikófaktorokat tárhatja fel (korábbi káresemények, esetleges kitiltások stb.). ${ }^{7}$ 
TAKÁCS DÁNIEL

Az ügyfélkapuval történő regisztráció vázlatos technikai folyamata:

1. Ügyfélkapus regisztráció (Kormányablakban vagy online - ez utóbbi megfelelő elektronikus tanúsítvány - aláírókártya - birtokában helyben, személyes megjelenés nélkül végezhető el, ennek hiányában pedig egy hónap áll rendelkezésre az így elvégzett ideiglenes regisztráció személyes véglegesítésére).

2. Autentikáció a könyvtárban (a létező vagy újonnan létrehozott könyvtári nyilvántartási egységhez - felhasználói törzs - rendelt természetes vagy egyéb adatok egyeztetése a kormányzati adatbázissal, amely viszontazonosítással vagy elutasítással zárul).

3. Ha még nem szerepelt az adott személy a könyvtári nyilvántartásban, akkor új nyilvántartási egység készítése vagy a korábban már létezett összekapcsolása az ügyfélkapus entitással.

4. Adatok frissítése, karbantartása.

5. Amennyiben már rendelkezik az adott felhasználó könyvtári nyilvántartási egységgel más intézménynél, a kapcsolódó egyéb információkhoz való hozzáférés biztosítása a kurrens intézmény számára, ahol az új regisztrációs folyamat zajlik (vagy a hivatali kapun keresztül, vagy közvetlen adatkapcsolat segítségével).

6. Szolgáltatás használata.

Elönyök és hátrányok

A bevezetni javasolt rendszernek természetesen előnyei és hátrányai is vannak a többi megoldáshoz képest.

A hátrányok között elsőként kell megemlíteni a megfelelő jogi és technológiai környezet hiányát. A fejlesztési igényeket illetően szerencsére rendkívül jól dokumentált, könnyen adaptálható megoldásokról van szó, a jogi környezet kialakításában pedig mintát mutathatnak az állami és önkormányzati szolgáltatások és az ezzel kapcsolatos adatkezelés jelenleg is zajló szabályozása, tehát mindkét területen már kitaposott úton lehet járni.

Komoly kockázatot jelentenek azok az adatvédelmi kérdések, amelyek az egyes intézmények közötti adatcserére vonatkoznak. Mivel ezek érzékeny adatok, kezelésük kizárólag a felhasználó által jóváhagyott módon történhet, továbbításuk megfelelő szabályozás nélkül lehetetlen. További nehézséget jelenthet a felhasználók általi adaptáció, de mivel jelenleg a közigazgatás és a magánszektor számtalan területén zajlik hasonló folyamat, így a feladat is megoszlik. Megfelelő kampányokkal, oktatással, esetleg a KEKKH-val közös partneri viszony kialakításával lerövidíthető ez a tanulási folyamat.

Technikailag jelent problémát a külső félhez kötött infrastruktúra (azaz ha elérhetetlenné válik a magyarorszag.hu, akkor a szolgáltatásokat sem lehet igénybe venni), de ez csökkenthető az azonosítási lehetőségek számának növelésével (pl. egy tanúsítványos vagy ügyfélkapus regisztrációhoz utólag hozzá lehet rendelni egy facebookos, google-s, twitteres fiókot). Az intézményrendszer szempontjából komoly veszély, hogy nem megfelelő szakmai koordináció esetén a fejlesztési munka további fragmentálódáshoz vezethet a könyvtári rendszereket illetően. 
$\mathrm{Az}$ itt ismertetett rendszer egyik legfontosabb előnye a nagyfokú rugalmasság, amellyel a törvényi (pl. az interoperabilitással összefüggő elvárások teljesítése), a technológiai (pl. új személyi igazolvány lehetőségeinek kihasználása, fejlett autentikációs megoldások megalapozása és támogatása), a szakmai (szorosabb kapcsolat az intézmények között, egységes technológiai platform kiépítése az összehangolt szolgáltatásfejlesztéshez) és a társadalmi (mobilitás támogatása, korszerú IT-eszközök használatának támogatása) elvárásokhoz tud igazodni.

Leegyszerűsíti a könyvtárak által vezetett felhasználói nyilvántartások kialakítását, az ezzel összefüggő szabványok megalkotását és alkalmazását (hiszen ezt a munkát elég egyszer elvégezni és rendszeresen felülvizsgálni, nem kell újra és újra létrehozni).

Növeli a felhasználó-központúságot, lehetővé téve, hogy egy adott személy ugyanazokat a személyre szabott szolgáltatásokat kaphassa meg az ország bármely pontján. Gyorsabb és pontosabb statisztikák előállítását teszi lehetővé, és nagymértékben segíti a folyamatok automatizálását (adat- és dokumentumküldési lehetőségek).

\section{További lehetöségek}

Végül szeretnék néhány olyan szolgáltatási lehetőséget felsorolni, amely a fentebb vázolt nyilvántartási és hitelesítési rendszeren alapulhat:

- A könyvtárközi kölcsönzés újradefiniálása: a szolgáltatást igénylő személy a távoli intézménnyel közvetlenül is kapcsolatba léphet, így a helyi könyvtár jogi és anyagi felelőssége megszűnik.

- A könyvtári szolgáltatások központi igénybevétele: egy központi szolgáltatási oldalon keresztül (ilyen lehetne pl. a konyvtar.hu címen jelenleg is múködő rendszer, de akár a magyarorszag.hu portálon keresztül is elérhetővé lehet tenni) elérhetővé válhatna bizonyos alapszolgáltatások köre (könyvtár- és dokumentumkeresés, beiratkozások, kölcsönzések központi kezelése stb.).

- Lakcím-változás alapján történő ajánlás: egy költözés, iskola- vagy egyetemváltás esetén a rendszer automatikus ajánlót tud összeállítani az új környéken található intézményekről és szolgáltatásaikról.

- Historikus adatok továbbítása (kölcsönzés, keresések stb.): új intézménybe történő beiratkozás esetén a korábbi könyvtárban kiépített információs, szolgáltatási környezet és preferenciák átkerülhetnek, így növelve a felhasználói élményt és a komfortérzetet, ráadásul megkíméli az olvasót a rekonstrukció adott esetben komoly erőfeszítésétől (például egy tanár vagy kutató esetében).

- Alkalmazásfejlesztés: olyan alkalmazások és szolgáltatások hozhatók létre, amelyek pontos jogosultsági körök mentén garantálják a hozzáférhetőséget (például dedikált hozzáférések esetén). Ennek segítségével megfelelő környezet alakítható ki a mobil és e-book környezetben a szerzői jogok betartása mellett a dokumentumokhoz történő távoli hozzáférés érdekében (például az Amazonhoz hasonló személyre szabott e-könyvtári környezet kialakítása elektronikus könyvolvasókon). 
TAKÁCS DÁNIEL

- Kapcsolat más szolgáltatásokkal: amennyiben a könyvtárakhoz is bekerülnek ezek a felhasználói információk, az intézmények lehetőségei is jócskán megnőnek a felhasználók segítése terén (pl. lakossági pályázatok írása, ügyintézésben való közremúködés). Megfelelő együttmúködési keretek között olyan információs felületek is létrehozhatók, ahol a könyvtár által nyújtott lehetőségek öszszekapcsolódhatnak az ügyfélkapuval elérhető szolgáltatásokkal és forrásokkal.

\section{Konklizió}

A rendelkezésre álló lehetőségek közül az egyik legolcsóbb és leghatékonyabb megoldás (mind a felhasználó, mind a fejlesztő, mind az üzemeltető számára) a kormányzati adatbázison alapuló ügyfélkapus azonosítás. A megoldás lehetőséget ad arra, hogy a szolgáltatások köre egyszerűen bővíthető legyen, és a jogosultsági szintek is rugalmasan alakíthatók a rendelkezésre álló szigorúbb vagy egyszerúbb egyéb azonosítási eljárások bevonásával. Az egységesítés további előnye, hogy a könyvtárak is összeköthetővé válnak, megvalósítva így országos szinten az egypontos beiratkozást, és megfelelő jogi szabályozás esetén az egy helyen kialakított szolgáltatási környezet bármely más intézménybe történő átvitelét is.

\section{Jegyzetek}

${ }^{1}$ 2011. évi CXII. törvényaz információs önrendelkezési jogról és az információszabadságról. Forrás: http://net.jogtar.hu/jr/gen/hjegy_doc.cgi?docid=A1100112.TV [2016. január 7.]

${ }^{2}$ 2013. évi CCXX. törvény az állami és önkormányzati nyilvántartások együttmúködésének általános szabályairól. Forrás: http://net.jogtar.hu/jr/gen/hjegy_doc.cgi?docid=A1300220. TV [2016. január 7.]

${ }^{3}$ 1997. évi CXL. törvény a muzeális intézményekről, a nyilvános könyvtári ellátásról és a közművelődésről. Forrás: http://net.jogtar.hu/jr/gen/hjegy_doc.cgi?docid=99700140.TV [2016. január 7.]

${ }^{4}$ Családi és utónév (születési és viselt), születési hely és idő, anyja neve.

${ }^{5}$ Az ügyfélkapu felhasználásainak statisztikáit a magyarorszag.hu közli. Forrás: https:/ / segitseg.[-] magyarorszag.hu/segitseg/portal/latogatottsagi_adatok.html [2016. január 7.]

${ }^{6}$ Olyan csatlakozási felület, amely lehetővé teszi a gép adatcserét két alkalmazás között.

${ }^{7}$ Az ilyen típusú információk kezelése természetesen nem képzelhető el a megfelelő intézményi policy és etikai szabályzat nélkül.

Takács Dániel szolgáltatási igazgató a Budapesti Ügyvédi Kamaránál, az ELTE Irodalomtudományi Doktori Iskola Könyvtártudomány Doktori Programjának hallgatója. 